ADRIANNA CZEKALSKA

Uniwersytet Łódzki

iD ORCID ID: 0000-0001-7076-0169
WŁADZA I POLITYKA

W CZASACH NOWOŻYTNYCH

DYPLOMACJA I SPRAWY WEWNĘTRZNE

\title{
Formalny i nieformalny status sekretarza polskiego korpusu dyplomatycznego na przykładzie misji w Kopenhadze (1792-1795)
}

The formal and informal status of the secretary Polish diplomatic corps on the example of the mission in Copenhagen (1792-1795)

$\mathrm{O}$

d czasów saskich polska polityka zagraniczna przeżywała regres, co było związane przede wszystkim z założeniami szlachty uważającej, że nieingerowanie w jakiekolwiek konflikty uchroni państwo przed ich negatywnymi rezultatami. Przekładało się to na wszelkie zagadnienie związane z dyplomacją, paraliżując tym samym polską służbę zagraniczną i powodując wykluczenie Rzeczypospolitej jako mniej lub bardziej liczącego się państwa na arenie międzynarodowej ${ }^{1}$.

Celem artykułu jest wskazanie najczęstszych i najważniejszych problemów, z jakimi musiał sobie radzić przedstawiciel dworu warszawskiego o nieuregulowanej pozycji dyplomatycznej. Zagadnienie organizacji odbudowywanej polskiej służby dyplomatycznej bez wątpienia nie zostało w pełni opracowane, zwłaszcza od strony administrowania poszczególnymi placówkami akredytowanymi przy zagranicznych dworach ${ }^{2}$.

Kiedy ostatecznie w grudniu 1788 r. Sejm Wielki postanowił oficjalnie wznowić państwową działalność dyplomatyczną, pojawił się problem powołania kompetentnych

${ }^{1}$ J. Gierowski, Dyplomacja doby saskiej (1699-1763), [w:] Historia dyplomacji polskiej, t. II (1572-1795), red. Z. Wójcik, Warszawa 1982, s. 337, 373, 388, 470, 472.

2 Autorzy sztandarowych opracowań dziejów polskiej polityki zagranicznej doby stanisławowskiej (J. Michalski czy Z. Anusik) omawiają obszernie najważniejsze zagadnienia związane ze służbą dyplomatyczną, jednak nie skupiają się bezpośrednio na problematyce administrowania legacjami. Jak dotąd, najlepiej zanalizowaną tematyką wydaje się kwestia polityki zagranicznej prowadzonej przez Stanisława Augusta w latach 1764-1788. M. Rymszyna w swojej monografii przedstawiła bowiem nie tylko ogólne założenia instytucji Gabinetu Jego Królewskiej Mości, ale również sposób jego organizacji i pracy. Eadem, Gabinet Stanistawa Augusta, Warszawa 1962. 
urzędników. Brakowało bowiem odpowiednio przygotowanych do tego osób, a pośród szlachty wciąż panowało przekonanie, że najważniejszym wyznacznikiem uzyskania statusu dyplomaty jest zamożność konkretnego kandydata ${ }^{3}$. Stanisławowi Augustowi, świadomemu, jak ważna jest polityka zagraniczna, nie sprzyjała również decyzja Sejmu o ograniczeniu królowi swobody w nominowaniu przedstawicieli na poszczególne placówki ${ }^{4}$. Nie mając bezpośredniego wpływu na obsadzenie szefów legacji, monarcha był zmuszony do posiłkowania się następnym w kolejności stanowiskiem, tj. sekretarzem misji ${ }^{5}$. Formalnie podczas nieobecności posła na placówce był on również jego zastępcą w charakterze chargé d'affaires ad interim. Warto w tym miejscu zaznaczyć, że były to jedyne funkcje w polskich korpusach z oficjalnym statusem dyplomatycznym opłacane ze skarbu Rzeczypospolitej, co potwierdzają tabele opłat i pensji ${ }^{6}$.

Stanowisko sekretarza mogło mieć o wiele większe znaczenie, niż można by przypuszczać. Z powodu braku ingerencji Sejmu w jego nominację Stanisław August miał bowiem możliwość wyboru przychylnej sobie osoby niepodzielającej poglądów konkretnego posła, czy będącej mu wręcz nieprzychylną. Zdarzyć się więc mogło, że legacja

${ }^{3}$ Dyariusz Seymu Ordynaryinego pod zwiazkiem Konfederacji Generalnej Oboyga Narodow w Warszawie rozpoczętego roku pańskiego 1788, t. I, cz. 1, Warszawa [b.m.w.], s. 194-195; ibidem, t. I, cz. 2, Warszawa 1790, s. 252, 257-258, 259-260, 276-278, 279, 280; Z. Anusik, Misja polska w Sztokholmie w latach 1789-1795, Łódź 1993, s. 18-19; idem, Organizacja i funkcjonowanie polskiej stużby zagranicznej w latach 1764-1792 (próba nowego spojrzenia), „Acta Universitatis Lodziensis. Folia Historica” 1996, z. 58, s. 61-62.

${ }_{4}^{4}$ Dyariusz Seymu Ordynaryinego, t. I, cz. 2, s. 291, 293-296, 297-302, 341, 349-353; J.I. Kraszewski, Polska w czasie trzech rozbiorów 1772-1799. Studia do historii ducha i obyczaju, t. II, Oświęcim 2015, s. 84, 87, 88, 89. W uchwale przyjęto zapis „My Król za zgodą Stanów wysyłamy”. Według J. Michalskiego słowo „wysyłamy” miało zapewnić kompromis między królem i tzw. stronnictwem patriotycznym, jednak nie wydaje się, aby zadowalało to monarchę. Wskazywać na to może bowiem podkreślenie w dalszym tekście uchwały, że Stanisław August mógł oddelegować na placówki zagraniczne jedynie za jednomyślnym przyzwoleniem pozostałych stanów sejmujących. Por. idem, Dyplomacja polska w latach 1764-1795, [w:] Historia dyplomacji polskiej, s. 654-655; Dyariusz Seymu Ordynaryinego, t. I, cz. 2, s. 370; Z. Anusik, Organizacja i funkcjonowanie, s. 63; W. Kalinka, Sejm Czteroletni, t. I, Warszawa 1991, s. 232-234.

5 Warto w tym miejscu przypomnieć, że szef legacji mógł również zatrudniać swojego osobistego sekretarza, będącego jego prywatnym urzędnikiem i niesprawującego żadnej dyplomatycznej funkcji. Wszystko było zależne od prywatnych orszaków towarzyszących dyplomatom. Por. Z. Anusik, Problemy życia codziennego na placówce dyplomatycznej w końcu XVIII wieku, [w:] Między barokiem a oświeceniem. Radości i troski życia codziennego, red. S. Achremczyk, Olsztyn 2009, s. 103.

${ }^{6}$ Oficjalny status dyplomatyczny posiadali także kapelani. Byli jednak akredytowani zaledwie przy trzech misjach: petersburskiej, sztokholmskiej i haskiej. Zdarzało się jednak, że korpus dyplomatyczny mógł liczyć jedną osobę więcej, czego przykładem jest placówka sztokholmska. Do czerwca 1792 r. przebywał bowiem na niej adiunkt, który - choć nie posiadał wspomnianego statusu - był opłacany ze skarbu Rzeczypospolitej. Por. Tabele optat pensji postów Rzeczpospolitej urzędujących za granica oraz wydatki nadzwyczajne postów i ministrów do zwrotu ze skarbu Rzeczpospolitej, AGAD, ZP, sygn. 408, k. 49, 188; S.E. Nahlik, Narodziny nowożytnej dyplomacji, Wrocław 1971, s. 155 i przyp. 109 na tej samej stronie; Z. Anusik, Misja polska w Sztokholmie, s. 43-44. 
zarządzana przez niechętnego monarsze dyplomatę ostatecznie uzyskiwała zwierzchnictwo dotychczasowego sekretarza legacji, który okazywał się królewskim zwolennikiem. Znajdujący się przy boku reprezentanta Rzeczypospolitej sekretarz, dysponując odpowiednimi - najczęściej prywatnymi - środkami pieniężnymi na wyekspediowanie poczty, mógł ponadto niezależnie informować Gabinet Jego Królewskiej Mości lub bezpośrednio monarchę o działalności misji. Nieformalnie więc sekretarz mógł być agentem królewskim, dzięki któremu Stanisław August uzyskiwał dodatkowe wiadomości o pracy nie tylko konkretnej misji polskiej, ale także pozostałych poselstw akredytowanych przy konkretnym dworze. O dużym stopniu samodzielności interesującego nas urzędnika świadczy także fakt, że szefowi placówki nie przysługiwała żadna możliwość wyciągnięcia konsekwencji niesubordynacji swojego potencjalnego zastępcy ${ }^{7}$.

Problem formalnego i nieformalnego statusu sekretarza pojawiał się jednak nie tylko w stosunkach personalnych między nim i posłem, ale także w oficjalnej pracy legacji. Aby uzyskać możliwość korzystania z pełni praw przysługujących zagranicznym reprezentantom, sekretarz zastępujący szefa placówki musiał otrzymać listy kredencjonalne, na podstawie których konkretny dwór formalnie uznawał jego nominację na chargé d'affaires. Niekiedy jednak pełnił tę funkcję nieformalnie, czego dobrym przykładem jest Antoni Kochanowski, który kilkukrotnie zastępował reprezentanta w Kopenhadze.

Wspomniany Kochanowski przybył na placówkę duńską w listopadzie 1789 r. (wraz z pierwszym ministrem pełnomocnym Adamem Wawrzyńcem Rzewuskim), przebywając na niej pięć lat ${ }^{8}$. Swojego zwierzchnika zastąpił już w kwietniu roku 1790. Wówczas nieobecność Rzewuskiego trwała zaledwie od jednego do dwóch tygodni,

${ }^{7}$ Dobrym przykładem na to jest konflikt J.M. Potockiego i J. Sierakowskiego, o którym swego czasu pisał Z. Anusik, Ktopoty pana sekretarza. Przyczynek do dziejów polskiej stużby zagranicznej w dobie Sejmu Czteroletniego, „Acta Universitatis Lodziensis. Folia Historica” 2001, z. 70, s. 83-109. W pierwszej kolejności problemy natury służbowej rozstrzygała Deputacja Interesów Zagranicznych, a po uchwaleniu Konstytucji 3 maja minister spraw zagranicznych w Straży Praw. Wspomniany badacz zauważył, że takie rozwiązanie miało zapobiec monopolizacji informacji przez którekolwiek ze stronnictw sejmowych. Por. Z. Anusik, Problemy życia codziennego, s. 106 i przyp. 11 na tej samej stronie; idem, Misja polska w Sztokholmie, s. 57.

${ }^{8}$ Pierwsza wiadomość wysłana z Kopenhagi nosi datę 24 XI 1789 r. Oficjalnie pracę na placówce rozpoczęto między 24 a 30 XI, bowiem wówczas A.W. Rzewuski został przyjęty przez Chrystiana VII na audiencji. Por. J. Małachowski do A.W. Rzewuskiego, 12 XII 1789, Depesze ambasady polskiej w Kopenhadze z lat 1789-1793, [w:] Biblioteka Ossolińskich. Poczet Nowy, t. III, Lwów 1863, s. 167; J. Małachowski do A.W. Rzewuskiego, 12 XII 1789, B.Ossol., Korespondencja urzędowa deputacji interesów zagranicznych w Warszawie z poselstwem polskim u dworu duńskiego w Kopenhadze. Od 1789 do 1792, cz. 2, rkps 410/II, k. 1-3; J. Małachowski do A.W. Rzewuskiego, 12 XII 1789, B.Ossol., Korespondencja dyplomatyczna deputacji spraw zagranicznych w Warszawie i poselstwa polskiego w Danii oraz akta dotyczące stosunków zagranicznych Polski z lat 1773-1776 i 1789-1793, rkps 516/III, k. 43; A.W. Rzewuski, nr 1, 28 XI 1789, B.Ossol., Korespondencja urzędowa poselstwa polskiego przy dworze w Kopenhadze z Deputacją Interesów Zagranicznych w Warszawie z lat 1789-1791, rkps 410/III, k. 1; J. Małachowski do A.W. Rzewuskiego, 16 XII 1789, B.Ossol., Korespondencja urzędowa deputacji, cz. 2, rkps 410/II, 
co nie wymagało uregulowania statusu Kochanowskiego9 . Niespełna miesiąc później minister pełnomocny uzyskał jednak pozwolenie Deputacji Interesów Zagranicznych na definitywne opuszczenie urzędu. W depeszy z 13 maja 1790 r. Kochanowski poinformował kanclerza Jacka Małachowskiego, że został oficjalnie zaprezentowany duńskiemu ministrowi spraw zagranicznych, Andreasowi Peterowi von Bernstorffowi. Etykieta uniemożliwiała mu jednak uzyskanie królewskiego posłuchania nie tylko dlatego, że dwór udawał się wówczas na letnie mieszkanie, ale przede wszystkim z powodu braku listów kredencjonalnych. Według protokołu bowiem należałoby zorganizować nadzwyczajną audiencję, przysługującą jedynie osobom formalnie akredytowanym właśnie wspomnianymi dokumentami ${ }^{10}$.

Sprawy ceremoniału były jednak najmniejszym problemem wobec rzeczywistych kłopotów nieformalnego chargé d'affaires. Na sekretarza spadł nie tylko trud jednoosobowego prowadzenia placów - to jest brania udziału w konferencjach i bardziej lub mniej oficjalnych spotkaniach - ale przede wszystkim finansowania misji ${ }^{11}$. Warto pamiętać, że Kochanowski nie uzyskiwał pensji pełnomocnego posła, lecz tą przysługującą funkcji, którą formalnie pełnił, czyli sekretarza. W pierwszej kolejności musiał opłacać siedzibę poselstwa oraz pocztę, a także organizować obiady czy mniejsze bankiety dla uzyskania przychylności pozostałych dyplomatów. Skoro ekwiwalenty przyznawane szefom legacji nie wystarczały na pokrycie wydatków, przez co ci zadłużali się u zagranicznych bankierów i opłacali rachunki z prywatnej szkatuły, to pensja sekretarza tym bardziej nie była w stanie zaspokoić finansowych potrzeb poselstwa, mimo

k. 6-7; J. Małachowski do A.W. Rzewuskiego, 16 XII 1789, B.Ossol., Korespondencja dyplomatyczna deputacji, rkps 516/III, k. 44.

9 A.W. Rzewuski do J. Małachowskiego, 20 III 1790, B.Ossol., Korespondencja urzędowa poselstwa polskiego, rkps 410/III, k. 12; J. Małachowski do A.W. Rzewuskiego, 31 III, 1790, B.Ossol., Korespondencja urzędowa deputacji, rkps 410/II, k. 14; J. Małachowski do A.W. Rzewuskiego, 31 III 1790, B.Ossol., Korespondencja dyplomatyczna deputacji, rkps 516/III, k. 50; A.W. Rzewuski, 10 IV 1790, B.Ossol., Korespondencja urzędowa poselstwa polskiego, rkps 410/III, k. 17; A. Kochanowski do J. Małachowskiego 17 IV 1790, B.Ossol., Korespondencja urzędowa poselstwa polskiego, rkps 410/III, k. 19; J. Małachowski do A.W. Rzewuskiego, 17 IV 1790, B.Ossol., Korespondencja urzędowa deputacji, cz. 2, rkps 410/II, k. 16; J. Małachowski do A.W. Rzewuskiego, 17 IV 1790, B.Ossol., Korespondencja dyplomatyczna deputacji, rkps 516/III, k. 53.

10 A. Kochanowski do J. Małachowskiego, 15, 18 i 22 V 1790, B.Ossol., Korespondencja urzędowa poselstwa polskiego, rkps 410/III, k. 21; J. Małachowski do A.W. Rzewuskiego, 15 V 1790, B.Ossol., Korespondencja urzędowa deputacji, cz. 2, rkps 410/II, k. 18; J. Małachowski do A.W. Rzewuskiego, 15 V 1790, B.Ossol., Korespondencja dyplomatyczna deputacji, rkps 516/III, k. 55.

${ }^{11}$ Placówka kopenhaska nie była jedyną jednoosobową legacją Rzeczypospolitej. Po wyjeździe z Hagi M.K. Ogińskiego podobna sytuacja spotkała A. Middletona. W świetle ówczesnej dokumentacji figuruje jednak jako misja dwuosobowa, bowiem ze skarbu Rzeczypospolitej opłacany był również kapelan oddelegowany na tamtejszą placówkę. Por. S. Meller, Stosunki polsko-holenderskie w latach 1790-1795, Warszawa 1974, s. 204; Tabele optat pensji postów, k. 406. 
przyznania Kochanowskiemu podwyżki o tysiąc czerwonych złotych. Zrozumiałym byłoby również, gdyby posłowie wyżsi rangą odmówili wchodzenia w bardziej zażyłe relacje z osobą o nieuregulowanym statusie dyplomatycznym. Kochanowski mógł mieć również utrudniony dostęp do przedstawicieli rządu kopenhaskiego. Prowadzenie jednoosobowej placówki było także kłopotliwe w przypadku mniejszych lub większych problemów zdrowotnych, o czym polski przedstawiciel przekonał się w listopadzie 1791 r., kiedy to schorowany spędził w swojej siedzibie dwa tygodnie. Wówczas, aby zapewnić sobie ciągły przepływ informacji, poprosił o pomoc Karla Heinricha Jonanna Wilhelma von Görtza (saskiego ministra); chodziło o przekazywanie mu wiadomości dotyczących interesujących go zagadnien ${ }^{12}$.

Kochanowski pozostawał na nieuregulowanym statusie dyplomatycznym ok. pół roku. W listopadzie roku 1790 kanclerz Małachowski przekazał mu, że Sejm nominował na ministra pełnomocnego do Kopenhagi kasztelana sądeckiego Józefa Ankwicza. Dygnitarz przyznał jednak, że powodem tej decyzji było ostatecznie nadanie duńskiemu chargé d'affaires w Warszawie, Edmundowi Bourke'owi, rangi nadzwyczajnego przedstawiciela na miejsce ministra rezydenta Nielsa Rosenkrantza, który od lipca 1789 r. przebywał w Petersburgu ${ }^{13}$. Wydaje się więc, że Sejm nie planował rozwiązywać problemów administracyjno-organizacyjnych legacji kopenhaskiej. Zastawia również, dlaczego nie postanowiono po prostu podnieść Kochanowskiemu funkcji, wysyłając mu kolejnego sekretarza lub pozostawiając go na jednoosobowej placówce z podwyższoną pensją, będącą jednak niewątpliwie niższą od sumy obu uposażeń wypłacanych dotychczasowemu sekretarzowi i nowemu ministrowi. Nadużyciem nie będzie stwierdzenie, że najbardziej prawdopodobnym powodem był brak doświadczenia i umiejętności posłów w kwestiach prowadzenia polityki zagranicznej oraz przeświadczenie o nieprzydatności placówki akredytowanej w Danii.

Nowy minister pełnomocny ostatecznie przybył do Kopenhagi 17 marca 1791 r., uzyskując pierwszą audiencję na dworze Oldenburgów 23 marca. Na misji spędził jednak zaledwie pół roku, otrzymując z końcem września 1791 r. zezwolenie na powrót do Rzeczypospolitej. Powodem wystosowania prośby przez Ankwicza były straty finansowe, jakie poniósł podczas swojego pobytu w Danii ${ }^{14}$. Kochanowski kolejny

${ }_{12}$ Repertorium der diplomatischen Vertreter aller Länder, Bd. III (1764-1815), hrsg. O.F. Winter, Graz-Köln 1965, s. 371.

13 A. Kochanowski do J. Małachowskiego, 3 i 10 VII 1790, 10 VIII 1790, B.Ossol., Korespondencja urzędowa poselstwa polskiego, rkps 410/III, k. 30; J. Małachowski do A. Kochanowskiego, 17 XI 1790, B.Ossol., Korespondencja urzędowa deputacji, cz. 2, 410/II, k. 29; J Małachowski do A. Kochanowskiego, 27 XI 1790, B.Ossol., Korespondencja dyplomatyczna deputacji, rkps 516/III, k. 70; Repertorium der diplomatischen, s. 50, 52.

${ }^{14}$ J. Ankwicz do J. Małachowskiego, 25 III 1791, B.Ossol., Korespondencja urzędowa poselstwa polskiego, sygn. 410. III, k. 16; Nr 54, dnia 18 grudnia [1790], Depesze ambasady polskiej, s. 197; Nr 14, 
raz został więc nieformalnym zastępcą polskiego ministra pełnomocnego, pozostając z nieuregulowanym statusem dyplomatycznym aż do jesieni roku 1793 . Wówczas to bowiem zdecydowano się ostatecznie mianować go oficjalnym chargé d'affaires ad intermin $^{15}$. Niemniej jednak formalnie nadana funkcja przysporzyła Kochanowskiemu więcej kłopotów niż pożytku, ponieważ niedługo po nadesłaniu mu listów kredencjonalnych Rzeczpospolita zaczęła likwidować swoje zagraniczne placówki. Ostatecznie więc Kochanowski z formalnym statusem chargé d'affaires akredytowany na formalnie zlikwidowanej placówce prowadził do 1795 r. jako formalny „zakładnik” nieformalną działalność dyplomatyczną, nadsyłając do Warszawy kolejne depesze informujące o sytuacji politycznej w Kopenhadze. W wyniku długów zaciągniętych przez legację nowy chargé d'affaires nie mógł jednak swobodnie powrócić do kraju, będąc swego rodzaju gwarantem w ich spłacie.

W tym miejscu warto wspomnieć o umiejętnościach Kochanowskiego i przydatności jego relacji. Brak formalnie uregulowanego urzędu nie uniemożliwiał danemu dyplomacie uzyskania dokładnych informacji w interesujących go kwestiach. Nawet gdyby nieoficjalny chargé d'affaires miał ograniczony dostęp do konferencji z zagranicznymi ministrami, zawsze mógł wykorzystać swoje kontakty z pozostałymi członkami konkretnych korpusów dyplomatycznych lub też pomniejszymi przedstawicielami rządowymi czy dworskimi. Wiadomości nadsyłane przez Kochanowskiego faktycznie były szczegółowe, jednak nie przynosiły niczego, co mogłoby zostać uznane przez Rzeczpospolitą za godne uwagi. Sekretarz opisywał w nich zwyczaje panujące na dworze kopenhaskim i skupiał się na ewentualnym konflikcie szwedzko-duńskim, pomijając wszelkie sprawy związane bezpośrednio lub pośrednio z dworem warszawskim nawet wtedy, kiedy wspominali o nich jego korespondenci - kanclerz Małachowski czy późniejszy kanclerz wielki litewski Joachim Chreptowicz. Dobrym przykładem na to jest kwestia związana $\mathrm{z}$ ewentualnym wybuchem wojny austriacko-pruskiej w lipcu 1790 r., którą to wzmiankę Kochanowski zbagatelizował, pozostawiając ją bez żadnego komentarza i przechodząc do dokładnego opisu poczynań księdza Jana Chrzciciela Albertrandiniego przybyłego kilka dni wcześniej do Kopenhagi w celu m.in. przeprowadzenia kwerendy w królewskiej bibliotece ${ }^{16}$. Nasuwa się wniosek, że

dnia 19 marca 1791, ibidem, s. 197; Nr 15, dnia 25 marca 1791, ibidem, s. 199; J. Chreptowicz do J. Ankwicza, 7 IX 1791, B.Ossol., Korespondencja urzędowa JMP. Chreptowicza, kanclerza litewskiego, ministra do interesów zagranicznych w Warszawie. Od 1791 do 1793, cz. 2, rkps 411/II, k. 43.

15 A. Kochanowski do J. Chreptowicza, 14 X 1793, B.Ossol., Korespondencja urzędowa poselstwa polskiego, sygn. 412/III, k. 36; A. Kochanowski do J. Chreptowicza, 12 XI 1793, ibidem, k. 41.

${ }^{16}$ Ksiądz J.C. Albertrandi wracał z placówki sztokholmskiej, na której sprawował funkcje kapelana. Duchowny podczas podróży odwiedzał biblioteki w poszukiwaniu dokumentów cennych dla historii Rzeczypospolitej. A. Kochanowski zobowiązał się wystarać u A.P. Bernstorffa pozwolenie na wysłanie do Warszawy wszystkich manuskryptów pisanych w języku polskim w celu ich skopiowania. A. Kochanowski do J. Małachowskiego, 24 VII 1790, B.Ossol., Korespondencja urzędowa poselstwa polskiego, rkps 410/ 
polski przedstawiciel wiedział, co należy do obowiązku dyplomaty, jednak ze zdobytych przez siebie informacji nie potrafil wybrać tych, które mogły się okazać istotne dla dworu warszawskiego. Niemniej najbardziej zaskakuje brak relacji dotyczących w mniejszym lub większym stopniu konwencji w Reichenbach z lipca 1790 r. Możemy jednak zadać sobie pytanie, dlaczego warszawscy korespondenci Kochanowskiego nie instruowali go, na co ma zwracać baczniejszą uwagę. Swoimi mało przydatnymi wiadomościami sekretarz upewniał więc Rzeczpospolitą o nieprzydatności placówki akredytowanej w Danii, co nie było zupełną prawdą. O przychylności jaką minister Bernstorff żywił wobec Polaków świadczą depesze wcześniejszych ministrów pełnomocnych. Niejednokrotnie wspominali oni bowiem, że hrabia przekazał im pewne informacje dotyczące Polski otrzymane od pozostałych dyplomatów, ostrzegając i radząc przy tym, na co Polacy powinni zwrócić szczególną uwagę. Legacja kopenhaska mogła być również doskonałym źródłem informacji z powodu polityki neutralności, która zmuszała tamtejszy rząd do uzyskiwania dokładnych wiadomości z każdej placówki, co umożliwiało dygnitarzom królewskim umiejętne lawirowanie między wszystkimi dworami.

W ramach podsumowania należy zaznaczyć, że problem formalnego i nieformalnego statusu sekretarza polskiej misji spowodowany był m.in. brakiem odpowiednio wykształconego personelu zajmującego się polityką zagraniczną. Mimo że istniały pewne uregulowania określające zadania i prawa zastępcy ministra pełnomocnego, to niedostatecznie dokładne konstytucje czy kodeksy powodowały, iż jego nieformalny status często brał górę nad formalnym, a ponadto mógł uczynić z niego „podwójnego agenta”. O ile w stosunkach pomiędzy nim i jego zwierzchnikiem groziło to konfliktem, o tyle w pracy samej legacji niekoniecznie musiało paraliżować jej działalność. Nadużyciem nie będzie stwierdzenie, że uzyskiwanie interesujących wiadomości zależało w największym stopniu od umiejętności danego przedstawiciela akredytowanego przy konkretnym dworze. Chociaż Kochanowski przez większość swojego pobytu w Danii pozostawał z nieuregulowanym statusem dyplomatycznym, to miał szansę pozyskiwać przydatne informacje, w czym pomogliby mu nie tylko członkowie pozostałych placówek, lecz sam minister Bernstorff. Niewątpliwie sekretarzowi łatwiej byłoby uzyskać przychylność innych posłów, gdyby dysponował większymi nakładami finansowymi umożliwiającymi mu organizację obiadów, bankietów, a niekiedy zapewne dającymi ewentualność przekupstwa dla uzyskania pewnych nowin. Brak doświadczenia dyplomatycznego zarówno polskiego przedstawiciela, jak i jego warszawskiej zwierzchności, a także obojętność, z jaką postrzegano legację kopenhaską, zaważył jednak na niepełnym wykorzystaniu jej potencjału.

III, k. 25; Z. Anusik, Misja polska w Sztokholmie, s. 44-45; W. Konopczyński, Polska a Szwecja. Od pokoju oliwskiego do upadku Rzeczypospolitej 1660-1795, Kraków-Warszawa 2016, s. 318; K. Chodynicki, Albertrandy Jan Chrzciciel, [w:] PSB, t. I, Kraków 1935, s. 45-46. 
Jak zostało zaznaczone we wstępie, artykuł nie wyczerpuje zagadnienia organizacji polskich placówek akredytowanych przy zagranicznych dworach. Problem ten niewątpliwie wymaga dokładniejszej i bardziej obszernej analizy, w tym porównania wszystkich dotychczas opracowanych misji dyplomatycznych powołanych przez Sejm Wielki.

\begin{abstract}
When the Great Sejm in 1788 decided to appoint a state foreign service, there was a problem of lack of appropriate officials and right. There were no regulations specific to the work of Polish diplomats posted to foreign royal courts. An example of how imprecise the organizational assumptions of Polish foreign policy resumed in December 1788 is the status of a secretary of the legation, who could act as chargé d'affaires formal and informal. The article does not exhaust the entire subject matter, but merely mentions some of the problems that the representative with an unregulated diplomatic position had to deal with.
\end{abstract}

\title{
Keywords
}

Diplomacy, the Great Sejm, chargé d'affaires, the foreign service, Stanisław August Poniatowski. 